\title{
PEMURIDAN ALKITABIAH MENURUT INJIL YOHANES UNTUK ANAK USIA DINI ERA REVOLUSI INDUSTRI 4.0
}

Oleh :

Yuliati

Dosen Tetap STT Gamaliel

Email: yuliatitrifena@gmail.com

\begin{abstract}
ABSTRAK - Anak usia dini harus membiasakan diri dengan kemajuan teknologi informasi di era Industri 4.0. Namun kemajuan teknologi informasi ini memiliki dampak negatif bagi anak usia dini. Pendampingan orang tua diusulkan untuk menangkal dampak negatif kemajuan teknologi. Bahkan pendampingan orang tua dapat dimanfaatkan untuk mempersiapkan kerohanian anak dalam menghadapi tantangan era Industri 4.0 melalui pemuridan. Penelitian ini bertujuan untuk mengaplikasikan pemuridan menurut Injil Yohanes dalam pemuridan anak usia dini di era Industri 4.0. Penelitian ini adalah penelitian terapan dengan pendekatan kualitatif dan paradigma fenomenologi teologia. Penelitian ini menemukan Model Pemuridan Keluarga Yohanes 4.0 yang akan membantu orang tua untuk mendidik anak usia dini menjadi seorang murid Kristus.
\end{abstract}

Kata Kunci: Anak Usia Dini, Pemuridan, Keluarga, Yohanes, Era Industri 4.0

\begin{abstract}
Chidren in early childhood must adjust themseft about advance in information technology in Industrial 4.0 era. However this advance in information technology has negative impact to children. Parental accompaniment is proposed to prevent negative impact of technology advance. Even parental accompaniment can be use to prepare the spirituality of the child to face the challenge from Industrial 4.0 era. This research aims to apply discipleship according to The Gospel of John on early childhood discipleship in Industrial 4.0 era. This reseach is an applied reaseach that use qualitative approach and fenomenology theology paradigm. This research produce Family John 4.0 discipleship model that will help parent to educate children in early childhood become disciple of Christ.
\end{abstract}

Keyword: Chidren in early childhood, Discipleship, Family, John, Industrial 4.0 Era

\section{PENDAHULUAN}

Kemajuan peradaban dan kehidupan manusia di era industri 4.0 ini ditandai dengan globalisasi dan perkembangan yang sangat cepat di bidang teknologi, informasi, dan komunikasi. Kemajuan ini mendorong manusia harus berhubungan dengan teknologi informasi. Bahkan tidak 
hanya manusia dewasa, anak-anak usia dini juga terpengaruh kemajuan teknologi ini. Salah satu contohnya adalah anak usia dini sudah mulai mengenal gawai, smartphone, aplikasi dan permainan virtual.

Anak usia dini yang telah merasakan kemajuan teknologi informasi ini tentu memiliki keunggulan. Mereka akan lebih cerdas, kreatif, dan trampil menggunakan sarana teknologi. Kecerdasan dan kreatifitas anak ini diperoleh karena smartphone menawarkan sistem pembelajaran visual. ${ }^{1}$ Anak usia dini dapat segera belajar tentang warna, huruf, dan bentuk. Mereka juga dapat mengembangkan pola pikir untuk membuat strategi melalui permainan elektronik. $^{2}$ Inilah sebagian dampak positif kemajuan teknologi kepada anak.

Dampak positif kemajuan teknologi informasi menjadi jawaban bagi tantangan di era industri 4.0 yaitu pandemi Covid-19. Teknologi informasi dimanfaatkan untuk melaksanakan kegiatankegiatan yang terhambat akibat pandemi Covid-19. Contoh terkait penerapan teknologi informasi di pandemi Covid-19 adalah sekolah daring termasuk Pendidikan Anak Usaia Dini (PAUD). ${ }^{3}$ PAUD daring

\footnotetext{
${ }^{1}$ Wahyu Novitasari and Nurul Khotimah, "DAMPAK PENGGUNAAN GADGET TERHADAP INTERKSI SOSIAL ANAK USIA 5-6 TAHUN," JurnaI PAUD Teratai 5, no. 3 (2016): 183.

2 Puji Asmaul Chusna, "Pengaruh Media Gadget Pada Perkembangan Karakter Anak," Dinamika Penelitian: Media Komunikasi Sosial Keagamaan 17, no. 2 (2017): 317-318, https://eresources.perpusnas.go.id:2093/doi/abs/10.1142/ s0192415X20500500.

${ }^{3}$ Moch. Surya Hakim Irwanto, "IMPLEMENTASI KOLABORASI ORANG TUA DAN GURU DALAM PELAKSANAAN PEMBELAJARAN DARING PADA PAUD," JIEES : Journal of Islamic Education at Elementary School 1, no. 1 (2020): 17.
}

menjadi solusi untuk menghadirkan layanan pendidikan anak usia dini di rumah. Contoh lain adalah pelayanan kerohanian Kristen. Gereja mengadakan ibadah daring untuk melayani jemaat di rumah termasuk anak-anak usia dini. ${ }^{4}$

Teknologi informasi memang memberikan dampak positif kepada anak. Namun dibalik dampak positif ini, teknologi informasi memiliki dampak negatif yang berbahaya. Gawai komunikasi mordern seperti smartphone dapat berakibat pada pertumbuhan otak yang terlalu cepat, sulit tidur, dan agresif. ${ }^{5}$ Smartphone juga membuat anak-anak sulit berelasi secara sosial dengan orang lain. ${ }^{6}$ Selain itu masih ada bahaya lain seperti pornografi, kejahatan, atau tayangan lain yang merusak iman dan moral. Ibadah daring (online) yang dilakukan gereja belum dapat menggantikan ibadah luring (offline) karena terbatasnya penghayatan ketika ibadah daring. ${ }^{7}$ Oleh karena itu, penerapan teknologi informasi di pelayanan anak usia dini era industri 4.0 memerlukan strategi khusus.

Penelitian Irwanto menyimpulkan bahwa pembelajaran daring pada PAUD memerlukan peran orang tua untuk

\footnotetext{
${ }^{4}$ Onisimus Langfan, "Ibadah Online Di Masa Pandemi Covid-19: Implementasi Ibrani 12:28," Stella 1, no. 1 (2021): 15-16.

${ }^{5}$ Jordan Efraim Palar, Wenda Oroh, and Franly Onibala, "Hubungan Peran Keluarga Dalam Menghindari Dampak Negatif Penggunaan Gadget Pada Anak Dengan Perilaku Anak Dalam Penggunaan Gadget Di Desa Kiawa 2 Barat Kecamatan Kawangkoan Utara," Jurnal Keperawatan 6, no. 2 (2018): 4-5.

${ }^{6}$ Putri Hana Pebriana, "Analisis Penggunaan Gadget Terhadap Kemampuan Interaksi Sosial Pada Anak Usia Dini," Jurnal Obsesi : Jurnal Pendidikan Anak Usia Dini 1, no. 1 (2017): 9-10. ${ }^{7}$ Langfan, "Ibadah Online Di Masa Pandemi Covid19: Implementasi Ibrani 12:28," 27.
} 
pendampingan dalam pembelajaran. ${ }^{8}$ Penelitian Pebriana juga menyarankan adanya pendampingan anak usia dini dalam penggunaan gawai untuk menghindari dampak negatif gawai. ${ }^{9}$ Penelitian Chusna juga menemukan bahwa orang tua harus mendampingi anak saat menggunakan gawai agar karakter anak tidak rusak oleh dampak negatif gawai. ${ }^{10}$

Pendampingan orang tua di era Industri 4.0 tidak cukup hanya sekedar untuk menangkal dampak negatif gawai saja. Pendampingan orang tua harus berpengaruh lebih karena adanya tantangan pandemi Covid-19 dan anak usia dini cenderung selalu dirumah saja. Penelitian Haryono menemukan bahwa kepemimpinan ayah dimasa pandemi Covid-19 mempengaruhi empat aspek kehidupan yaitu kerohanian, pendidikan, kesehatan, dan ekonomi. ${ }^{11}$ Pendampingan orang tua dapat dimanfaatkan sebagai usaha untuk menghasilkan generasi penerus yang berkualitas.

Peneliti hendak menemukan model pemuridan alkitabiah bagi anak usia dini. Alasan peneliti adalah peneliti hendak memaksimalkan pendampingan orang tua di era Industri 4.0 melalui pemuridan agar dapat meningkatkan kerohanian anak. Bagi peneliti kerohanian yang unggul akan memperbaiki pola pikir, kesehatan, karakter dan perbuatan yang menyimpang. ${ }^{12}$

\footnotetext{
${ }^{8}$ Irwanto, "IMPLEMENTASI KOLABORASI ORANG

TUA DAN GURU DALAM PELAKSANAAN

PEMBELAJARAN DARING PADA PAUD," 23.

${ }^{9}$ Pebriana, "Analisis Penggunaan Gadget Terhadap Kemampuan Interaksi Sosial Pada Anak Usia Dini," 10.

${ }^{10}$ Chusna, "Pengaruh Media Gadget Pada

Perkembangan Karakter Anak," 315.

${ }^{11}$ Timotius Haryono, "Implementasi Prinsip

Kepemimpinan Bapa Dalam Keluarga Kristen Di Era
}

Sehingga anak akan menjadi seorang generasi penerus keluarga, gereja, dan bangsa yang berkualitas.

Pemuridan akan membawa seseorang akan dibawa menjadi pribadi yang serupa Kristus yang memiliki kerohanian sempurna. ${ }^{13}$ Injil Yohanes sendiri juga memfokuskan pembahasan kepada Yesus dan pengajaran-Nya yang kurang diekspose di Injil lain. ${ }^{14}$ Keserupaan dengan Kristus ini akan membawa dampak yang besar salah satunya adalah kerohanian yang berkualitas.

\section{RUMUSAN MASALAH}

Rumusan masalah dalam penelitian ini adalah bagaimana aplikasi pemuridan menurut Injil Yohanes dalam pemuridan anak usia dini di era Industri 4.0?

Penelitian ini bertujuan untuk membuat sebuah model pemuridan yang alkitabiah bagi anak usia dini di era 4.0. Peneliti berharap melalui penelitian ini anak-anak usia dini dapat dididik sehingga memiliki kerohanian yang alkitabiah dan berkualitas.

Penelitian ini memiliki manfaat, yaitu: Pertama, secara teoritis, penelitian ini memperkaya keilmuan teologi praktika dalam bidang anak usia dini di era Industri 4.0. Kedua, secara praktis, penelitian ini dapat membantu pelayanan orang tua, gereja, komisi Sekolah Minggu, dan

\footnotetext{
New Normal Pandemi Covid-19," Thronos 2, no. 1 (2020): 1 .

12 Timotius Haryono, “Saved By Faith” (Sura:

Yayasan Gamaliel, 2018), 49.

${ }^{13}$ Santosa and Guntur Firman Aprianto, "Implementasi Penginjilan Dan Pemuridan Dalam Pengembangan Karakter Jujur Anak Usia 9-10 Tahun No Title," Teologi 2, no. 2 (2020): 100. ${ }^{14}$ Bruce Wilkinson and Kenneth Boa, Talk Thru The Bible (Malang: Penerbit Gandum Mas, 2017), 413.
} 
lembaga pelayanan anak dalam meningkatkan kerohanian anak usia dini di era Industri 4.0.

\section{METODE PENELITIAN}

Penelitian ini hendak memberi jawaban praktis terhadap suatu masalah sehingga masuk ke dalam kategori penelitian terapan. ${ }^{15}$ Penelitian ini mencari hubungan sebab akibat pada suatu peristiwa sosial menggunakan pendekatan kualitatif. ${ }^{16}$ Penelitian ini menggunakan paradigma fenomenologi teologi yaitu suatu paradigma yang menganggap bahwa Alkitab dan semua peristiwa di dunia ini adalah sumber dan obyek penelitian teologi. ${ }^{17}$ Peneiti berupaya menemukan prinsip pemuridan Injil Yohanes kemudian menerapkannya dalam pemuridan anak usia dini di era industri 4.0. Pengumpulan data dengan menggunakan metode studi pustaka yaitu penggalian teks Alkitab dan penelitian sumber-sumber pustaka yang terkait. Data yang dikumpulkan dalam penelitian ini adalah model pemuridan Injil Yohanes dan konteks anak usia dini era Industri 4.0. Data penelitian tersebut akan digunakan untuk menyusun model pemuridan anak usia dini alkitabiah era Industri 4.0

\section{HASIL DAN PEMBAHASAN Model Pemuridan Injil Yohanes}

Injil Yohanes memiliki perbedaan dibandingkan dengan Injil Matius, Markus, dan Lukas. Injil Yohanes menceritakan peristiwa pengajaran yang tidak didapati di

\footnotetext{
${ }^{15}$ Amir Hamzah, Metode Penelitian Kepustakaan (Library Research) (Batu: Literasi Nusantara, 2020), 5.

${ }^{16}$ Stevri Indra Lumintang and Danik Astuti Lumintang, Theologia Penelitian Dan Penelitian Theologis (Geneva Insani Indonesia, 2016), 98-99. 17 Ibid., 88-92.
}

tiga Injil sebelumnya. ${ }^{18}$ Injil Yohanes menfokuskan isinya untuk memperkenalkan Yesus yang adalah Allah yang memperkenalkan diri dalam rupa manusia di bumi dan berkurban menebus dosa manusia. ${ }^{19}$ berikut adalah model pemuridan dalam Injil Yohanes, yang meliputi komponen pemuridan dan proses pemuridannya.

\section{Komponen Pemuridan Injil Yohanes}

Komponen pemuridan dalam Injil Yohanes ditampilkan dengan Yesus sang pembuat murid, murid Yesus, materi pemuridan, metode pemuridan, sarana dan prasarana pemuridan. Berikut ini akan dijelaskan secara lebih detail komponenkomponen pemuridan tersebut.

Pertama, Yesus sang pembuat murid (guru). Yesus merupakan pembuat murid dalam model pemuridan Injil Yohanes. Yesus diperkenalkan sebagai Allah yang berinkarnasi menjadi manusia. ${ }^{20}$ Fakta Yesus adalah Firman Allah yang menjelma menjadi tertulis dalam Yohanes 1:1-18. ${ }^{21}$

Yesus dalam Injil Yohanes juga diperkenalkan sebagai guru. Kata 'guru' dalam Perjanjian Baru merupakan terjemahan dari bahasa Yunani 'didaskalos' dan pernah dipakai kata Ibraninya yaitu 'Rabbi.' Injil Yohanes melekatkan kata rabbi kepada Yesus sebanyak delapan kali $(1: 38 b ; 1: 49 ; 3: 2 ; 4: 31 ; 6: 25 ; 8: 4 ; 9: 2$;

\footnotetext{
18 Dave Hagelberg, Tafsiran Injil Yohanes (Yogyakarta: Yayasan Andi, 2001), 22-23.

${ }^{19}$ Wilkinson and Boa, Talk Thru The Bible, 413.

${ }^{20}$ Merril C. Tenney, Injil Iman (Malang: Gandum Mas, 2003), 70.

${ }^{21}$ Philip Johnston, IVP Introduction to the Bible (Bandung: Kalam Hidup, 2011), 311.
} 
11:8). ${ }^{22}$ Injil Yohanes memperkenalkan Yesus sebagai guru lebih banyak dari Injil yang lain.

Banawiratma menjelaskan bahwa gelar Guru memperlihatkan sifat pribadi Yesus. ${ }^{23}$ Gelar guru mengacu kepada gelar fungsional. Fungsi guru dipahami dari penjelasan Perjanjian Lama dimana Allah digambarkan sebagai guru bagi umat Israel (Yoh 6:45 band Yes 54:13). Karena gelas Guru tersebut, maka Yesus memiliki otoritas Ilahi. $^{24}$

J. Anthony menjelaskan bahwa Yesus merupakan guru yang sangat dekat dengan murid-murid-Nya. Bukti kedekatan ini yaitu Yesus peka terhadap pola pikir dan perasaan murid-murid-Nya. Yesus juga terbuka terhadap orang-orang yang rindu berelasi dengan Dia. ${ }^{25}$

Yesus juga adalah seorang guru yang penuh kasih. Wujud kasih terbesar Yesus adalah karya penebusan di kayu salib yang tidak hanya menebus dosa para murid tetapi juga semua manusia (Yoh 18-20). Namun tidak hanya karya penebusan saja, Yesus mewujudkan kasihnya kepada murid-murid-Nya dengan mendoakan mereka (Yoh 17). Yesus juga menyediakan makanan untuk para murid (Yoh 6:1-14; 21:1-14).

Penjelasan tentang Yesus diatas menunjukkan kualifikasi seorang pembuat murid atau guru dalam model pemuridan Injil Yohanes. Pembuat murid harus memiliki otoritas yang dari Allah seperti Yesus. Ia harus memiliki kedekatan dengan

\footnotetext{
22 Daniel Sutoyo, "Yesus Sebagai Guru Agung," Jurnal Antusias 3, no. 5 (2014): 69, http://www.sttintheos.ac.id/ejournal/index.php/antusias/article/view/13. 23 J. B. Banawiratma, Yesus Sang Guru (Yogyakarta: Yayasan Kanisius, 1997), 3.
}

muridnya dan terbuka untuk membangun relasi khususnya dengan muridnya. Terakhir pemurid harus penuh kasih untuk selalu memperhatikan dan mendoakan muridnya.

Kedua, murid Yesus. Injil Yohanes mencatat banyak orang mengikut Yesus. Orang banyak yang mengikuti Yesus dapat dibagi menjadi tiga kelompok. Kelompok pertama yaitu dua belas murid Yesus dan para wanita yang menjadi pengikut-Nya. Kelompok kedua yaitu orang-orang dari bangsa Yahudi, ahli-ahli Taurat, dan orangorang Farisi. Kelompok pertamalah yang dalam penelitian ini disebut murid Yesus. Kelompok orang inilah yang menerima pribadi Yesus, ajaran Yesus, dan mempercayai Yesus. ${ }^{26}$ Kelompok kedua secara jelas menolak Yesus beserta ajaranNya.

Pengenalan dan penerimaan Yesus sebagai Sang Guru adalah syarat yang penting dalam pemuridan Yesus dalam Injil Yohanes. Syarat ini adalah awal untuk mengikuti proses pemuridan yang kerjakan oleh Yesus. Syarat berikutnya adalah seorang murid Yesus harus rela diajar dan menaati perintah-perintah-Nya.

Bill Hull menjelaskan ada lima tanda murid dalam sekolah kerabian pada konteks Injil Yohanes. Tanda yang pertama, seseorang dikatakan murid bila menundukkan diri kepada gurunya. Tanda kedua, seorang murid akan menghafal semua ucapan gurunya. Tanda ketiga, murid akan belajar tentang cara-cara

\footnotetext{
24 Ibid., 115.

${ }^{25}$ Michael J. Anthony, Fondasi Pendidikan Abad 21

(Malang: Penerbit Gandum Mas, 2017).

${ }^{26}$ BIII Hull, Panduan Lengkap Pemuridan

(Yogyakarta: Yayasan Gloria, 2014), 26.
} 
pelayanan dari sang guru. Tanda yang keempat, bila seorang mencontoh teladan hidup guru, maka dia adalah seorang murid. Tanda kelima, seorang dikatakan murid bila dipaksa oleh gurunya untuk mencari murid untuk dirinya sendiri. ${ }^{27}$

Heath membedah kata mathetes (murid dalam bahasa Yunani) dan menemukan empat makna murid Yesus. Pertama, seorang menjadi murid Yesus ketika dia bertobat secara pribadi dan menerima Yesus sebagai Tuhan dan Juru Selamat. Kedua, murid Yesus merupakan seorang yang belajar kepada Yesus sang guru agung. Ketiga, murid Yesus akan tunduk kepada otoritas Yesus sehingga taat kepada setiap perintah-Nya. Keempat, murid Yesus adalah seorang yang mau mengikuti Yesus dalam berbagai kondisi. ${ }^{28}$ Murid dalam model Injil Yohanes, berdasarkan penjelasan diatas, memiliki empat kualifikasi. Kualifikasi pertama yaitu sudah bertobat dan menerima Yesus sebagai Tuhan dan juru selamat. Kualifikasi kedua adalah mempelajari setiap ajaran Yesus. Kualifikasi ketiga, menerapkan setiap teladan dan ajaran Yesus dalam kehidupannya. Kualifikasi keempat, setia mengikut Yesus dalam berbagai kondisi. Kualifikasi kelima yaitu mau mengajak orang lain untuk mengikut Yesus.

Ketiga, materi pemuridan. Materi pemuridan Yesus dalam Injil Yohanes adalah materi pembelajaran yang dari Allah (Yoh 6:45; 7:16). Sagala berpendapat bahwa Yesus adalah Allah karena

\footnotetext{
27 Ibid., 11.

${ }^{28}$ Stanley Heath, Masih Ditantang Dan Masih

Menantang (Bandung: Institut Alkitab Tiranus, 2005), 20-21.

${ }^{29}$ Mangapul Sagala, Firman Menjadi Daging

(Jakarta: Perkantas, n.d.), 65.
}

perbuatan dan Firman-Nya sesungguhnya merupakan perbuatan dan perkataan dari Allah sendiri. ${ }^{29}$ Secara lebih detail berikut adalah ajaran Yesus: ajaran pertama, seorang murid harus belajar Firman Tuhan secara terus menerus (Yoh 5:38).$^{30}$ Firman Tuhan yang dimaksudkan Firman Allah Israel dalam kitab-kitab perjanjian lama dan Firman Yesus yang didengar para murid. Kesimpulan yang dapat diambil dari penjelasan ini adalah materi pemuridan menurut Injil Yohanes adalah perkataan Allah dan perkataan Yesus yang saat ini dikenal dengan Alktiab.

Keempat, metode pemuridan. Injil Yohanes mencatat metode pemuridan Yesus. Metode pemuridan pertama adalah metode demonstrasi pelayanan. Yesus dalam Injil Yohanes melakukan tujuh mukjizat, berargumentasi dengan ahli Taurat, dan mengajar Kitab Suci. Dalam seluruh kegiatan Yesus, para murid ada dan menyaksikan bahkan terlibat secara langsung. Para murid mendapatkan pengalaman yang nyata tidak hanya sekedar teori. ${ }^{31}$ Dengan metode ini pula para murid benar-benar tahu siapa Yesus sehingga para murid semakin diyakinkan bahwa Yesus adalah Allah.

Metode pemuridan kedua yaitu pembelajaran melalui keteladanan Yesus. Kitab Yohanes memberikan narasi tentang Yesus yang melakukan ajaran yang Ia ajarkan. Peristiwa Yesus membasuh kaki murid-murid-Nya memberi teladan para murid untuk saling melayani (Yoh 13:1-

\footnotetext{
${ }^{30}$ Herman N. Ridderbos, Injil Yohanes Suatu

Tafsiran Teologis (Surabaya: Momentum, 2012), 332.

${ }^{31}$ Hull, Panduan Lengkap Pemuridan, 142.
} 
20). Peristiwa berikutnya dalam Yohanes 13:21-30) dikisahkan bahwa Yesus menegur Yudas dan Petrus. Peristiwa ini menjadi teladan bagi para murid untuk mengoreksi kesalahan sesama dan mengarahkan kepada kebaikan. Dengan metode ini para murid dapat diyakinkan bahwa ajaran Yesus adalah benar dan tanpa ragu mengikut Yesus. Selain itu, para murid juga tahu Yesus tidak munafik karena perkataan Yesus sama dengan tindakanNya.

Metode pemuridan ketiga yaitu melalui pertemuan khusus. Injil Yohanes pasal 13- 17 mencatat bahwa Yesus dan para murid merayakan hari raya Roti Tidak Beragi dengan menyembelih domba Paskah dan makan bersama (Yoh 13:1-2 band. Luk 22:7). Pada kesempatan ini Yesus memberikan pengajaran kepada murid-murid-Nya sekaligus menjawab pertanyaan dari para murid-Nya. Kesempatan ini juga digunakan Yesus untuk mengevaluasi perilaku, sikap, dan pengetahuan para murid yang menyimpang.

Kelima, sarana dan prasarana pemuridan. Yesus dan para murid hidup bersama selama kurang lebih tiga tahun. Kemana Yesus pergi disitu murid-muridNya berada (Yoh 7:3). Intensitas pertemuan yang tinggi, memungkinkan pelaksanaan pemuridan dimana saja dan kapan saja. Oleh karena itu, Yesus menggunakan apa saja yang ada disekitarnya menjadi sarana dan prasarana pemuridan. Salah satu contohnya adalah ketika Yesus berjalan diatas air (Yoh 6:15-21). Yesus menggunakan badai yang dihadapi para murid

\footnotetext{
32 BIIl Hull, Jesus Christ, Disciplemaker (Surabaya: Literatur Perkantas Jawa Timur, 2015), 11.
}

untuk menyatakan dirinya adalah pribadi yang berkuasa.

\section{Proses Pemuridan Injil Yohanes}

Proses pemuridan yang dilakukan Yesus dalam Injil Yohanes memiliki beberapa tahap. Tahap pertama, Yesus memperkenalkan diri dan memanggil orang-orang untuk menjadi murid Yesus. Yohanes 1: 24-51 mencatat bahwa Yohanes pembaptis memberitakan dan memperkenalkan kepada orang-orang tentang siapa Yesus. Beberapa orang mendengar perkataan Yohanes pembaptis dan menjumpai Yesus. Yesus kemudian mengajak orangorang yang mendatanginya untuk menjadi murid-Nya.

Tahap kedua, Yesus mendidik orang-orang yang menjadi muridnya. Orang-orang yang memutuskan untuk menjadi murid Yesus akan dididik dengan materi dan metode yang telah disebutkan di bagian komponen pemuridan Injil Yohanes. Pemuridan dilakukan dengan intensitas tinggi karena para murid mengikuti Yesus kemanapun selama sekitar tiga tahun (Yoh 7:3). ${ }^{32}$ Tujuan akhir Yesus adalah menjadikan para murid menjadi pembuat murid generasi berikutnya atau mneruskan pelayanan Yesus (Yoh 4).

Tahap ketiga, Yesus mengutus para murid-Nya untuk meneruskan pelayanannya. Narasi Injil Yohanes 21:15-19 mencatat Yesus yang mengutus Petrus untuk menggembalakan domba-domba Allah. Dengan kata lain dapat disimpulkan bahwa Yesus meminta Petrus untuk menjadi pembuat murid seperti Yesus. Hasil yang diharapkan melalui pengutusan 
ini adalah supaya semakin banyak orang percaya Yesus dan menjadi murid Kristus (Yoh 1:12; 5:24).

\section{Konteks Anak Usia Dini Masa Kini}

Anak usia dini adalah manusia yang berada pada rentang usia 0-8 tahun. ${ }^{33}$ Pendapat para ahli psikologi dan paedagogi, mengatakan bahwa anak usia dini adalah masa emas atau Golden Age untuk pertumbuhan dan pembentukan kepribadiannya. Masa ini merupakan masa yang penting untuk memaksimalkan kemampuan manusia dari berbagai aspek. Silahuddin mengatakan bahwa masa usia dini menentukan kualitas anak di masa dewasa. ${ }^{34}$

Karakteristik perkembangan anak usia dini memiliki ciri yang khusus. Maxim mengatakan ada empat karakter perkembangan anak usia dini. ${ }^{35}$ Perkembangan secara fisik anak usia dini memiliki tanda peningkatan keaktifan dalam melakukan kegiatan. Perkembangan secara kemampuan bahasa, anak usia dini sudah dapat mengerti perkataan orang tua dan menyampaikan pendapat meskipun secara terbatas. Perkembangan secara kognitif, anak usia dini mulai ingin tahu segala sesuatu yang ditandai dengan peningkatan intensitas bertanya. ${ }^{36}$ Perkembangan secara sosial, anak usia dini mulai dapat bermain bersama dengan teman sebayanya meskipun sikap egosentrisnya cukup tinggi.

\footnotetext{
${ }^{33}$ Widarmi D. Wijana, Modul 1: Konsep Dasar Pendidikan Anak Usia Dini (Surakarta: Universitas Sebelas Maret Surakarta, n.d.), 16.

${ }^{34}$ Silahuddin, "Urgensi Membangun Karakter Anak Sejak Usia Dini," Bunayya 3, no. 2 (2017): 18.

${ }^{35}$ Luluk Asmawati, Perencanaan Pembelajaran PAUD (Bandung: Rosdakarya, 2014), 27.
}

\section{Kebutuhan Rohani Anak Usia Dini}

Anak usia dini memiliki banyak kebutuhan. Kebutuhan rohani adalah salah satu diantaranya. Pada bagian latar belakang telah digambarkan penelitian ini berfokus pada pemuridan yang akan mencukupi kebutuhan rohani anak usia dini. Karena itu pada bagian ini, peneliti hanya akan menguraikan kebutuhan kerohanian anak usia dini.

Anak usia dini butuh mengerti tentang agama. Pengertian tentang agama adalah seperti nilai-nilai agama, pengenalan akan Tuhan, tata cara peribadahan dan doa, serta implementasi keagamaan terhadap kehidupan. Pasal 1 Peraturan Pemerintah RI dalam Sistem Pendidikan Nasional (PP) 55 Tahun 2007 mengarahkan bahwa setiap Pendidikan Agama Kristen agar murid aktif mengembangkan kemampuannya sehingga memperoleh kekuatan rohani keagamaannya. ${ }^{37}$ Wujud kekuatan rohani ini adalah karakter, kecerdasan, dan kemampuan yang berguna bagi dirinya dan masyarakat.

Agama Kristen meyakini bahwa semua orang telah berbuat dosa (Rom 3:23). Alkitab juga menunjukkan upah dosa ialah maut yang adalah hukuman Allah (Rom 6:23). Keberdosaan ini juga dimiliki oleh anak usia dini karena dia adalah manusia. Karena keberdosaan ini juga, anak usia dini membutuhkan keselamatan dari hukuman maut seperti manusia yang lain. ${ }^{38}$

Kebutuhan anak usia dini yang terkait dengan Industri 4.0 adalah teknologi. Maulana dan Nurhafizah mengatakan ada

\footnotetext{
${ }^{36}$ Khadijah, Pengembangan Kognitif Anak Usia Dini (Medan: Perdana Publishing, 2016), 63-77.

${ }^{37}$ Kementerian Hukum dan HAM RI, Peraturan Pemerintah Republik Indonesia Nomor 55 Tahun 2007, 2007, 2.

38 Haryono, "Saved By Faith."
} 
tiga keterampilan yang harus dikuasai di era Industri 4.0. Keterampilan tersebut adalah literasi digital, teknologi, dan literasi manusia. ${ }^{39}$ Anak usia dini perlu dipersiapkan untuk dapat bertahan di era ini dimana pendidikan anak sudah mulai berpindah menuju pendidikan daring.

Kesimpulan uraian diatas menunjukkan bahwa kebutuhan anak usia dini adalah pengertian tentang Agama Kristen, keselamatan dalam Yesus, dan pengetahuan teknologi.

\section{Pemuridan Alkitabiah Anak Usia Dini di Era Industri 4.0}

Model pemuridan Injil Yohanes dapat diaplikasikan untuk menjawab kebutuhan anak usia dini di era Industri 4.0. Penerapan model pemuridan Injil Yohanes dalam konteks anak usia dini akan menghasilkan model pemuridan yang baru. Peneliti menamakan model pemuridan yang baru ini dengan nama Model Pemuridan Keluarga Yohanes 4.0. Model pemuridan ini disebut keluarga karena model pemuridan ini dilaksanakan dalam keluarga dimana anak usia dini lebih banyak menghabiskan waktunya pada era Industri 4.0. Model pemuridan ini disebut Yohanes karena berdasarkan model pemuridan Injil Yohanes. Model ini bernama 4.0 karena model ini akan memperkenalkan teknologi kepada anak usia dini agar anak siap menghadapi era Industri 4.0. Model pemuridan tersebut memiliki tujuan pemuridan, komponen pemuridan dan proses pemuridan berikut penjelasannya.

\section{Tujuan Pemuridan}

\footnotetext{
${ }^{39}$ Ihsan Maulana and Nurhafizah Nurhafizah, “ANALISIS KEBIJAKAN PENDIDIKAN ANAK USIA DINI
}

Tujuan khusus dalam Model Pemuridan Keluarga Yohanes 4.0 yaitu pertama, memperkenalkan siapa Tuhan sang pencipta. Kedua, pemuridan ini bertujuan untuk memperkenalkan status anak sebagai pribadi yang diciptakan, dikasihi dan dihargai Tuhan. Tujuan ketiga adalah mendidik anak dalam ajaran dan nasehat Tuhan. Tujuan keempat adalah memperlengkapi anak dengan nilai-nilai Kristen agar dapat bertumbuh menjadi pribadi yang serupa Kristus.

Model Pemuridan Keluarga Yohanes 4.0 memiliki tujuan umum dan tujuan fungsional. Tujuan umum model pemuridan ini adalah membantu meletakan dasar ke arah perkembangan sikap, pengetahuan, ketrampilan dan daya cipta sehingga dapat menyesuaikan diri dengan lingkungan. Model pemuridan ini memiliki lima tujuan fungsional yaitu mengembangkan seluruh kemampuan yang dimiliki anak sesuai dengan tahap perkembangannya, mengenalkan anak kepada dunia sekitar, mengembangkan sosialisasi anak, mengenalkan peraturan dan menanamkan disiplin pada anak, memberikan kesempatan kepada anak untuk menikmati masa bermainnya.

\section{Komponen Pemuridan}

Model pemuridan Keluarga Yohanes 4.0 memiliki lima komponen pemuridan. Komponen pertama yaitu orang tua sebagai pembuat murid. Orang tua menjadi pemurid karena orang tualah yang dapat memenuhi kualifikasi seperti dalam model pemuridan Injil Yohanes. Anak 
adalah anugerah dari Allah. Dengan kata lain, orang tua diberikan kepercayaan oleh Allah untuk mendidik anak sehingga anak bisa mengenal Allah dan Firman-Nya. Oleh karena itu, orang tua memiliki otoritas ilahi untuk memimpin anak usia dini. Dengan demikian orang tua perlu menerima Yesus sebagai Tuhan dan Juru Selamatnya secara pribadi serta telah menjadi murid Yesus agar otoritas ilahi dapat terpancar dengan maksimal.

Orang tua merupakan pribadi yang dapat memiliki relasi yang dekat dengan anak usia dini. Anak usia dini akan menghabiskan banyak waktunya bersama orang tua dirumah karena belum memiliki relasi sosial yang luas. Terlebih lagi ketika di era Industri 4.0 saat ini dimana ada pandemi Covid-19, mereka harus dirumah saja. Intensitas perjumpaan yang tinggi dapat digunakan untuk berelasi serta membangun hubungan dalam pemuridan antara orang tua dan anak usia dini.

Orang tua merupakan pribadi yang secara normal (dalam kondisi normal) akan mengasihi anaknya. Orang tua akan terus memperhatikan, mendoakan dan mencukupi kebutuhan anak sebagai wujud kasihnya. $^{40}$ Tentu kasih ini harus di perbaharui didalam Yesus karena kasih Allah lebih dari kasih orang tua.

Komponen kedua yaitu anak usia dini sebagai murid Yesus. Untuk menjadi murid, anak usia dini harus bertobat dan menerima Yesus. Orang tua harus menyampaikan berita keselamatan agar anak usia dini bertobat dan menerima Yesus. Setelah terima Yesus, anak harus didorong untuk

\footnotetext{
${ }^{40}$ Yanto Paulus Hermanto et al., "Sikap Hormat Anak Terhadap Orang Tua Berdasarkan Prinsip Alkitab," Evangelikal: Jurnal Teologi Injili dan Pembinaan Warga Jemaat 5, no. 1 (2021): 82.
}

mau mempelajari ajaran Yesus dan menerapkannya dalam kehidupan sehingga anak usia dini dapat setia mengikut Yesus. Anak usia dini juga perlu ditanamkan kerinduan untuk membuat murid dihari-hari kedepan.

Komponen ketiga, materi pembelajaran. Materi dalam model pemuridan ini adalah Alkitab (Perjanjian Lama dan Perjanjian Baru) seperti model pemuridan dalam Injil Yohanes. Peneliti menyarankan pemuridan dapat dimulai dengan surat 1-3 Yohanes kemudian baru melanjutkan ke kitab-kitab yang lain. Surat 1-3 Yohanes menurut peneliti memiliki isinya sesuai dengan tujuan khusus pemuridan ini. Peneliti meyakini dengan memulai dengan surat 1-3 Yohanes dan Injil Yohanes anak usia dini akan memiliki dasar yang kuat sebelum belajar kitab-kitab lain.

Surat 1-3 Yohanes dapat menjawab kebutuhan anak usia dini. Surat 1-3 Yohanes mengajarkan tentang identitas Yesus (1 Yoh 1:1-4), kepastian pengampunan dosa (1 Yoh 1:5-2:2), ketaatan anakanak Allah (1 Yoh 2:3-17), pengetahuan tentang anti-Kristus (1 Yoh 2:18-27), identitas anak-anak Allah (1 Yoh 2:28$3: 10$ ), cara mengasihi yang benar (1 Yoh 3:11-24), pengenalan akan Roh Allah (1 Yoh 4:1-6), cara mengasihi Allah dan sesama (1 Yoh 4:7-21), kemenangan atas dunia (1 Yoh 5:1-5), kepastian keselamatan (1 Yoh 5:6-13), kepastian jawaban doa (1 Yoh 5:14-21), kesetiaan dalam kebenaran (2 Yoh 1:1-13), dan hidup dalam kebenaran (3 Yoh 1:1-15). ${ }^{41}$

\footnotetext{
${ }^{41}$ Timotius Haryono, Teguh Dalam Kristus (Surakarta: Yayasan Gamaliel, 2018).
} 
Komponen keempat, metode pembelajaran. Model Pemuridan Keluarga Yohanes 4.0 menggunakan tiga metode pembelajaran. Metode pembelajaran yang pertama adalah melalui demonstrasi pelayanan. Demonstrasi pelayanan dilakukan melalui melibatkan anak usia dini dalam kegiatan pelayanan orang tua maupun pergumulan keluarga. Sebagai contoh ketika orang tua membantu saudara dengan memberi makanan, anak usia dini dapat dilibatkan dengan menemani orang tua ketika membungkusnya. Contoh yang lain adalah ketika anggota keluarga sakit, anak usia dini dapat dilibatkan untuk mendoakan.

Metode pembelajaran kedua menggunakan keteladanan orang tua. ${ }^{42}$ Orang tua harus meneladankan anak untuk menerapkan ajaran yang dipelajari dalam proses pemuridan. Sebagai contoh ketika belajar tentang mengutamakan Tuhan dan telah disepakati tentang waktu penggunaan gawai, orang tua harus konsekuen dengan kesepakatan tersebut dengan tidak menggunakan gawai ketika ibadah keluarga. Metode pembelajaran ini penting karena dapat mendidik anak dalam penggunaan gawai secara tepat

Metode pembelajaran ketiga adalah melalui pertemuan rutin. Model Pemuridan Keluarga Yohanes 4.0 mendorong keluarga untuk mengadakan pertemuan rutin. Pertemuan rutin ini diadakan untuk menyampaikan materi dengan skala yang lebih besar dari relasi sehari-hari. Selain untuk menyampaikan materi dengan skala besar, pertemuan rutin digunakan untuk

\footnotetext{
${ }^{42}$ Hermanto et al., "Sikap Hormat Anak Terhadap Orang Tua Berdasarkan Prinsip Alkitab," 86.

${ }^{43}$ Timotius Haryono and Yuliati, Pemuridan Kontekstual (Surakarta: Yayasan Gamaliel, 2018),
}

mengevaluasi pertumbuhan rohani anak dan membangun relasi melalui kegiatan bersama. Pertemuan rutin ini dapat berupa Kelompok Tumbuh Bersama Kontekstual $(\mathrm{KTBK})^{43}$, permainan bersama anak dan orang tua baik permainan convensional maupun digital, ibadah keluarga, dan melihat film rohani anak bersama-sama. Peneliti menyarankan pertemuan rutin ini setidaknya seminggu sekali diluar ibadah minggu gereja.

Komponen kelima yaitu sarana dan prasarana pemuridan. Model Pemuridan Keluarga Yohanes 4.0 dilaksanakan di rumah karena disitulah anak usia dini lebih banyak menghabiskan waktu. Oleh karena itu, model ini menggunakan hal-hal apa saja yang ada di rumah untuk mendukung pemuridan. Orang tua dapat mengunakan barang-barang sehari-hari untuk menerangkan ajaran Alkitab. Model Pemuridan Keluarga Yohanes 4.0 mengharapkan keluarga memiliki gawai modern (seperti smarphone, televisi dan komputer) sehingga dapat mengenalkan teknologi kepada anak usia dini.

\section{Proses Pemuridan}

Model Pemuridan Keluarga Yohanes 4.0 memiliki tiga tahap dalam proses pemuridan. Tahap pertama adalah tahap proklamasi Yesus. Target dari tahap ini adalah anak usia dini bertobat dan menerima Yesus secara pribadi. Pembahasan dalam pemuridan akan lebih difokuskan pada tentang siapa Allah, siapa Yesus, keberdosaan manusia, dan keselamatan dalam Yesus. Orang tua pada tahap

http://stt-gamaliel.ac.id/index.php/bukureferensi/. 
ini perlu meminta respon pribadi anak usia dini apakah mereka mau menerima Yesus atau tidak.

Tahap kedua merupakan tahap pemuridan. Pada tahap ini, anak mulai diajarkan tentang ajaran dan nilai-nilai kekristenan. Tahap ini merupakan pelayanan lanjutan dari tahap sebelumnya. Oleh karena itu orang tua perlu memastikan bahwa anak telah sungguh-sungguh bertobat dan menerima Yesus. Tahap ini bertujuan agar anak mengerti ajaran Yesus dan menerapkannya dalam kehidupan.

Tahap ketiga adalah tahap pengutusan. Pengutusan yang dilakukan disini hanya dalam skala kecil karena anak usia dini masih sangat bergantung orang tua. Namun, anak usia dini perlu dilatih untuk terjun dalam pelayanan agar kerinduan untuk mendidik orang lain dapat ditanamkan. Contoh kegiatan yang dapat dipilih adalah mendoakan teman, memberi pengemis dan bersaksi di sekolah minggu.

\section{KESIMPULAN}

Aplikasi pemuridan menurut Injil Yohanes dalam pemuridan anak usia dini di era Industri 4.0 dapat dengan menerapkan Model Pemuridan Keluarga Yohanes 4.0. Model pemuridan ini disebut keluarga karena model pemuridan ini dilaksanakan dalam keluarga dimana anak usia dini lebih banyak menghabiskan waktunya pada era Industri 4.0. Model pemuridan ini disebut Yohanes karena berdasarkan model pemuridan Injil Yohanes. Model ini bernama 4.0 karena model ini akan memperkenalkan teknologi kepada anak usia dini agar anak siap menghadapi era Industri 4.0. Dengan menerapkan model ini, anak usia dini akan memiliki iman yang kokoh dan dapat menggunakan teknologi dengan tepat. Hasil akhir yang diharapkan adalah anak usia dini siap menghadapi tantangan era Industri 4.0.

\section{REFERENSI}

Anthony, Michael J. Fondasi Pendidikan Abad 21. Malang: Penerbit Gandum Mas, 2017.

Asmawati, Luluk. Perencanaan Pembelajaran PAUD. Bandung:

Rosdakarya, 2014.

Banawiratma, J. B. Yesus Sang Guru. Yogyakarta: Yayasan Kanisius, 1997.

Chusna, Puji Asmaul. "Pengaruh Media Gadget Pada Perkembangan Karakter Anak." Dinamika Penelitian: Media Komunikasi Sosial Keagamaan 17, no. 2 (2017): 315-330. https://eresources.perpusnas.go.id:2093/doi/ab s/10.1142/S0192415X20500500.

Hagelberg, Dave. Tafsiran Injil Yohanes. Yogyakarta: Yayasan Andi, 2001.

Hamzah, Amir. Metode Penelitian Kepustakaan (Library Research). Batu: Literasi Nusantara, 2020.

Haryono, Timotius. "Implementasi Prinsip Kepemimpinan Bapa Dalam Keluarga Kristen Di Era New Normal Pandemi Covid-19." Thronos 2, no. 1 (2020): 1-13.

_. "Saved By Faith." Sura: Yayasan Gamaliel, 2018.

—. Teguh Dalam Kristus. Surakarta: Yayasan Gamaliel, 2018.

Haryono, Timotius, and Yuliati.

Pemuridan Kontekstual. Surakarta:

Yayasan Gamaliel, 2018. http://sttgamaliel.ac.id/index.php/bukureferensi/.

Heath, Stanley. Masih Ditantang Dan Masih Menantang. Bandung: Institut Alkitab Tiranus, 2005.

Hermanto, Yanto Paulus, Christine Christine, Guntur Hari Mukti, Christopher Santoso, and Yonas Pasiran Ady Prayitno. "Sikap Hormat Anak Terhadap Orang Tua 
Berdasarkan Prinsip Alkitab."

Evangelikal: Jurnal Teologi Injili dan

Pembinaan Warga Jemaat 5, no. 1

(2021): 80-87.

Hull, BIll. Jesus Christ, Disciplemaker.

Surabaya: Literatur Perkantas Jawa

Timur, 2015.

_. Panduan Lengkap Pemuridan.

Yogyakarta: Yayasan Gloria, 2014.

Ihsan Maulana, and Nurhafizah

Nurhafizah. "ANALISIS

KEBIJAKAN PENDIDIKAN ANAK

USIA DINI DI ERA REVOLUSI

INDUSTRI 4.0." Jurnal Pendidikan

Tambusai 3, no. 2 (2019): 657-665.

Irwanto, Moch. Surya Hakim.

"IMPLEMENTASI KOLABORASI

ORANG TUA DAN GURU DALAM

PELAKSANAAN

PEMBELAJARAN DARING PADA

PAUD." JIEES : Journal of Islamic

Education at Elementary School 1, no. 1 (2020): 17-24.

Johnston, Philip. IVP Introduction to the Bible. Bandung: Kalam Hidup, 2011.

Kementerian Hukum dan HAM RI.

Peraturan Pemerintah Republik

Indonesia Nomor 55 Tahun 2007, 2007.

Khadijah. Pengembangan Kognitif Anak

Usia Dini. Medan: Perdana

Publishing, 2016.

Langfan, Onisimus. "Ibadah Online Di

Masa Pandemi Covid-19:

Implementasi Ibrani 12:28." Stella 1, no. 1 (2021): 15-28.

Lumintang, Stevri Indra, and Danik Astuti Lumintang. Theologia Penelitian Dan Penelitian Theologis. Geneva Insani Indonesia, 2016.

Novitasari, Wahyu, and Nurul Khotimah.

"DAMPAK PENGGUNAAN

GADGET TERHADAP INTERKSI

SOSIAL ANAK USIA 5-6 TAHUN."

Jurnal PAUD Teratai 5, no. 3 (2016):

182-186.

Palar, Jordan Efraim, Wenda Oroh, and Franly Onibala. "Hubungan Peran
Keluarga Dalam Menghindari

Dampak Negatif Penggunaan Gadget

Pada Anak Dengan Perilaku Anak

Dalam Penggunaan Gadget Di Desa

Kiawa 2 Barat Kecamatan

Kawangkoan Utara." Jurnal

Keperawatan 6, no. 2 (2018): 1-8.

Pebriana, Putri Hana. "Analisis

Penggunaan Gadget Terhadap

Kemampuan Interaksi Sosial Pada

Anak Usia Dini." Jurnal Obsesi :

Jurnal Pendidikan Anak Usia Dini 1, no. 1 (2017): 1.

Ridderbos, Herman N. Injil Yohanes Suatu Tafsiran Teologis. Surabaya:

Momentum, 2012.

Sagala, Mangapul. Firman Menjadi Daging. Jakarta: Perkantas, n.d.

Santosa, and Guntur Firman Aprianto. "Implementasi Penginjilan Dan Pemuridan Dalam Pengembangan Karakter Jujur Anak Usia 9-10 Tahun No Title.” Teologi 2, no. 2 (2020): 94-108.

Silahuddin. "Urgensi Membangun Karakter Anak Sejak Usia Dini." Bunayya 3, no. 2 (2017): 18-41.

Sutoyo, Daniel. "Yesus Sebagai Guru Agung." Jurnal Antusias 3, no. 5 (2014): 64-85.

http://www.sttintheos.ac.id/ejournal/index.php/antusias/article/vie w/13.

Tenney, Merril C. Injil Iman. Malang: Gandum Mas, 2003.

Wijana, Widarmi D. Modul 1: Konsep Dasar Pendidikan Anak Usia Dini. Surakarta: Universitas Sebelas Maret Surakarta, n.d.

Wilkinson, Bruce, and Kenneth Boa. Talk Thru The Bible. Malang: Penerbit Gandum Mas, 2017. 